\title{
PENERAPAN HUKUM WARIS ISLAM DALAM PERKARA WARIS DI PENGADILAN AGAMA PAMEKASAN
}

\author{
Eka Susylawati \\ Jurusan Syari'ah dan Ekonomi STAIN Pamekasan, \\ Jln. Panglegur KM. 04 Pamekasan.email:ekasusylawati@gmail.com
}

\begin{abstract}
Abstrak
Pewarisan adalah proses perpindahan harta dari orang yang meninggal dunia kepada ahli warisnya. Dalam hukum waris di Indonesia masih berlaku pluralisme hukum yakni hukum waris adat, Barat dan Islam. Sebagai bagian dari hukum perdata dalam hukum waris dikenal adanya pilihan hukum (opsi hukum) sehingga masyarakat dapat memilih hukum waris yang akan dianutnya. Dengan adanya Undang-Undang Nomor 3 Tahun 2006 tentang Perubahan Undang-Undang Peradilan Agama, pilihan hukum bagi orang yang beragama Islam ketika berperkara di pengadilan ditiadakan sehingga akan secara otomatis akan menjadi kewenangan Pengadilan Agama dan Pengadilan Agama akan menerapkan hukum waris Islam.
\end{abstract}

\begin{abstract}
:
Inheritance is the process of property changing from someone who dies to their heir. In inheritance law in Indonesia still uses law plurality, they are custom, western and Islamic law. As a part of civil law in inheritance law is known alternative law in order that society can choose inherintance law which is taken. Because there is the law of number 3, 2006 about the change of religious justice law, so the choice of moslem who have problem in the justice is abolished that will automatically become the authorithy of religious justice and it will implement islamic inherintance law.
\end{abstract}

Kata kunci:

Penerapan, Hukum Waris Islam, Pengadilan Agama 


\section{Pendahuluan}

Perubahan sosial secara sosiologis merupakan ciri yang melekat dalam masyarakat yang disebabkan karena masyarakat mengalami suatu perkembangan. Hukum Islam telah diterapkan di Indonesia jauh sebelum adanya Negara Kesatuan Republik Indonesia, ${ }^{1}$ dalam merespon perkembangan zaman dituntut untuk memiliki fleksibilitas yang memadai agar tidak kehilangan daya jangkauannya. ${ }^{2}$ Dalam masyarakat Islam di Indonesia perkembangan hukum Islam tidak dapat dilepaskan dari perkembangan Peradilan Agama yakni sejak diberlakukannya Undang-Undang Nomor 7 Tahun 1989 tentang Peradilan Agama.

Kewenangan absolut Pengadilan Agama adalah memeriksa, memutus dan menyelesaikan perkara perdata tertentu bagi orang orang yang beragama Islam. Kekuasaan absolut tersebut diatur dalam Pasal 49 Undang-Undang Nomor 7 Tahun 1989 yang kemudian diperbaharui oleh UndangUndang Nomor 3 Tahun 2006 yakni penyelesaian sengketa dalam bidang perkawinan, kewarisan, wasiat, hibah, wakaf dan shadaqah, dan ekonomi syari'ah.

Hukum waris adalah aturan yang mangatur hubungan manusia tentang pemilikan harta yang timbul sebagai akibat dari suatu kematian. Harta yang ditinggalkan oleh seseorang yang telah meninggal dunia memerlukan pengaturan tentang siapa yang berhak menerimanya, berapa jumlahnya dan bagaimana cara mendapatkannya. ${ }^{3}$

Dalam ajaran hukum Islam, aturan Allah swt. tentang kewarisan dituangkan dalam hukum waris Islam. Sebagai

1 Afdol, Landasan Hukum Positif Pemberlakuan Hukum Islam dan Permasalahan Implementasi HukumKewarisan Islam (Surabaya: Airlangga Press, 2003), hlm. 19.

2 Ahmad Rofiq, Pemaharuan Hukum Islam di Indonesia (Yogyakarta: Gama Media, Yogyakarta, 2001), hlm. 12.

${ }^{3}$ Amir Syarifuddin, Hukum Kewarisan Islam (Jakarta: Prenada Media, 2004), hlm. 3. 
ajaran hukum waris Islam menuntut umat Islam untuk menjadikan pedoman dalam berbuat hal-hal yang berkenaan dengan waris. Apabila di kalangan umat Islam terjadi kematian dan yang mati meninggalkan harta maka selayaknya umat Islam harus merujuk kepada ajaran agama yang tertuang dalam faraid.

Kenyataan di masyarakat meskipun kewarisan merupakan ajaran agama namun tidak semua umat Islam mengetahui secara baik sebagaimana yang berlaku pada ajaran agama yang berkenaan dengan ibadah shalat, puasa ataupun ibadah lainnya. Di Indonesia bidang hukum waris masih berlaku pluralisme hukum, ${ }^{4}$ dimana tiga sistem hukum berlaku secara berdampingan yakni hukum waris Barat (BW), hukum waris adat dan hukum waris Islam. Dan hukum waris adat sebagai hukum waris yang asli dan timbul dari masyarakat mayoritas dianut dan diterapkan oleh masyarakat Indonesia termasuk oleh masyarakat yang beragama Islam. Sebagian masyarakat menganggap bahwa hukum waris Islam merupakan hukum yang sangat rumit dan sulit. Kondisi inilah yang merupakan salah satu penyebab hukum waris Islam masih sulit diterima oleh masyarakat Islam di Indonesia. ${ }^{5}$

Hukum waris merupakan salah satu bagian dari hukum perdata secara keseluruhan dan merupakan bagian terkecil dari

4 Pluralisme hukum sering disebut juga dengan keanekaragaman hukum. Keanekaragaman hukum perdata tersebut merupakan realita bahwa negara Indonesia terdiri dari berbagai suku bangsa, agama, dan adat istiadat. Perbedaan itu tercermin dalam tatahukum Indonesia yang keberadaannya masih disokong oleh hukum adat, hukum Islam dan hukum Barat. Hal ini dapat kita lihat dari norma dasar dalam Pasal II Aturan Peralihan UndangUndang Dasar 1945, yang merupakan kelanjutan dari politik hukum Pemerintah Hindia Belanda. (Lihat: Afdol dan Lilik Kamilah, Pola Pembagian Waris Berdasarkan Permohonan di Pengadilan Agama Surabaya dan Malang, Yuridika, Volume 14, Januari Pebruari 1999, hlm. 45).

${ }_{5}$ Abdullah Siddik, Hukum Waris Islam dan Perkembangannya di Seluruh Dunia Islam (Jakarta: Widjaja, 1984), hlm. 34. 
hukum kekeluargaan. ${ }^{6}$ Sebagai bagian dari hukum perdata dalam hukum waris mengenal adanya kebebasan memilih hukum. Berdasarkan asas kebebasan tersebut pada dasarnya ahli waris berhak untuk menentukan dan memilih hukum yang akan diterapkan dalam suatu pembagian waris. Apabila ahli waris menginginkan diselesaikan dengan menggunakan hukum waris adat atau Barat maka perkara warisnya diajukan ke Pengadilan Negeri. Sebaliknya apabila menginginkan untuk diselesaikan berdasarkan hukum waris Islam maka diajukan ke Pengadilan Agama.

Dalam Penjelasan Umum Undang-Undang tersebut dijelaskan bilamana pewarisan dilakukan berdasarkan hukum Islam, maka penyelesaiannya dilaksanakan oleh Pengadilan Agama. Kewarisan Islam diterapkan dalam rangka mewujudkan keseragaman kekuasaan Peradilan Agama di seluruh wilayah Indonesia, yang selama ini antara satu sama lainnya berbeda. ${ }^{7}$

Namun asas kebebasan dalam bidang waris bagi yang beragama Islam dianulir dengan adanya Undang-Undang Nomor 3 Tahun 2006. Opsi hukum dalam perkara waris yang sebelum adanya Undang-Undang tersebut masih diperkenankan namun kemudian dihilangkan sehingga apabila terdapat sengketa waris antarorang yang beragama Islam maka perkara warisnya secara otomatis akan menjadi kewenangan dari Pengadilan Agama. Berdasarkan Undang-Undangtersebut Pengadilan Agama dalam memeriksa dan memutus perkara akan menerapkan hukum waris Islam. Dengan demikian dalam saat ini asas personalitas ke-Islam-an dalam perkara waris adalah suatu yang mutlak.

\footnotetext{
${ }^{6}$ Eman Suparman, Intisari Hukum Waris Indonesia (Bandung: Mandar Maju, 1991), hlm. 1.

7 Abdul Mannan, Penerapan Hukum Acara Perdata di Lingkungan Peradilan Agama (Jakarta: Prenada Media Group, 2006), hlm. 14.
} 
Dalam praktik mayoritas masyarakat di Pamekasan mendasarkan kepada hukum waris adat dibandingkan dengan hukum waris Islam. Beberapa fakta antara lain bahwa orang tua memberi portie waris yang sama antara anak laki-laki dan perempuan (dalam hukum waris Islam 2:1 antara anak laki-laki dan anak perempuan) dan orang tua pada umumnya sudah membagi hartanya (dengan proses hibah) kepada anak-anaknya sebelum orang tua meninggal dunia. Kedua kebiasaan ini merupakan salah satu ciri hukum waris adat pada masyarakat parental.

Masyarakat Pamekasan pada umumnya mengurus Surat Keterangan Waris (sebagai salah satu persyaratan dalam membagi waris) ke kantor kecamatan setempat dimana di dalam Surat Keterangan Waris tersebut nantinya akan tertulis nama-nama ahli waris dengan mendasarkan kepada hukum waris adat.

Fakta-fakta di atas diperkuat dengan jumlah perkara waris yang diputus oleh Pengadilan Agama Pamekasan sangatlah minim. Berdasarkan rekapitulasi jumlah perkara waris sejak dihilangkannya opsi dalam hukum waris yakni tahun 2006 hingga tahun 2013 yaitu setiap tahunnya rata-rata hanya 1 (satu) atau 2 (dua) perkara saja. Hal tersebut menunjukkan bahwa tingkat penyelesaian perkara waris dengan mendasarkan pada hukum waris Islam di Pengadilan Agama Pamekasan masih sangat rendah.

Masalah pokok yang dikaji dalam penelitian ini adalah: Pertama, Apakah Pengadilan Agama Pamekasan selalu menerapkan hukum waris Islam dalam memeriksa dan memutus sengketa waris. Kedua, Kendala apa yang dihadapi oleh Hakim Pengadilan Agama Pamekasan dalam memutus sengketa waris dengan mendasarkan pada hukum waris Islam.

Manfaat dan tujuan penelitian ini adalah mengisi, memperluas dan memperkaya khasanah di bidang Ilmu Hukum khususnya tentang penerapan hukum waris Islam dalam perkara waris di Pengadilan Agama Pamekasan di 
tengah-tengah masyarakat Pamekasan yang masih menerapkan dan menganut hukum waris adat. Secara praktis, diharapkan dapat bermanfaat sebagai masukan bagi Badan Legislatif, Hakim Pengadilan Agama dan Pengadilan Negeri, akademisi, praktisi maupun masyarakat luas dalam rangka penerapan hukum waris Islam bagi orang yang beragama Islam dalam perkara waris di Pengadilan Agama.

Ruang lingkup penelitian ini menetapkan ruang lingkup atas pembatasan masalah dari sisi isu, subyek, dan lokasi. Isu yang menjadi kajian dalam penelitian ini adalah penerapan hukum waris Islam dalam sengketa waris di Pengadilan Agama Pamekasan yang menurut Undang-Undang bersifat mutlak. Amanat Undang-Undang tersebut berbeda dengan praktik di masyarakat yang menggunakan hukum waris adat. Dengan demikian dalam penerapan hukum waris tersebut tidak tertutup kemungkinan Hakim Pengadilan Agama menghadapi hambatan dalam memeriksa dan memutus karena mendasarkan pada asas personalitas ke-Islam-an. Penelitian ini sangatlah relevan dan penting karena nantinya dapat memberikan kesimpulan apakah putusan Pengadilan Agama dalam perkara waris menerapkan hukum waris Islam secara tekstual atau kontekstual.

Subyek penelitian ini adalah Hakim di Pengadilan Agama Pamekasan yang mempunyai peranan dan terlibat dalam mengadili dan memutus perkara waris yang diajukan oleh pihak-pihak yang beragama Islam. Subyek penelitian lainnya dalam rangka untuk memperoleh tambahan data adalah Panitera sekretaris Pengadilan Agama, Advokat maupun Notaris di Pamekasan. Alokasi waktu yang dibutuhkan sekitar 3 (tiga) bulan mulai Mei - Juli 2014.

\section{Metode Penelitian}

Penelitian ini menggunakan pendekatan analisis deskriptif kualitatif karena data yang dikumpulkan lebih banyak merupakan data kualitatif yaitu proses penelitian yang 
datanya disajikan dalam bentuk verbal bukan dalam bentuk angka, yang semaksimal mungkin berusaha mengungkapkan realitas asli untuk kemudian data dimaksud dianalisis dan diabstraksikan dalam bentuk teori sebagai tujuan akhir dari suatu penelitian. Realitas tersebut adalah dengan menggambarkan apakah Pengadilan Agama Pamekasan akan selalu menerapkan hukum waris Islam dalam perkara waris yang diajukan oleh masyarakat dan apakah Hakim Pengadilan Agama Pamekasan mengalami hambatan dalam menyelesaikan perkara waris dengan mendasarkan kepada hukum waris Islam.

Pendekatan tersebut dipadukan dengan rancangan penelitian hukum sosiologis (socio legal design). Dengan rancangan penelitian tersebut diharapkan dapat mendeskripsikan dan mengevaluasi secara empirik proses bekerjanya hukum dalam kehidupan masyarakat. ${ }^{8}$

Jika dilihat dari tujuannya, jenis penelitian ini dapat dikategorikan menggunakan metode deskriptif. Metode deskriptif adalah suatu metode yang digunakan dalam pencarian fakta status sekelompok manusia, suatu obyek, suatu kondisi, suatu sistem pemikiran ataupun peristiwa pada masa sekarang dengan interpretasi yang tepat.

Dengan jenis pendekatan ini dimaksudkan melakukan studi deskriptif terhadap penerapan hukum waris Islam dalam perkara waris di Pengadilan Agama dan apakah Majelis Hakim mengalami hambatan dalam menerapkan hukum waris Islam tersebut mengingat hukum waris yang mayoritas diterapkan oleh masyarakat adalah hukum waris adat.

Bilamana dilihat dari sifatnya, maka penelitian ini termasuk studi kasus atau penelitian lapangan. Diantara ciri-ciri studi kasus adalah mempelajari secara intensif tentang latar

8 Soetandyo Wigjosoebroto, Hukum : Paradigma Metode dan Dinamika Masalahnya (Jakarta: Elsam dan Huma, 2002), hlm. 34. 
belakang dan posisi saat ini, serta interaksi lingkungan unit sosial tertentu yang bersifat apa adanya (given). ${ }^{9}$

Sumber data utama dalam penelitian kualitatif adalah kata-kata atau tindakan, dan selebihnya adalah data tambahan seperti dokumen. Sumber data dalam penelitian ini dibagi dalam 2 (dua) kategori, yaitu data primer dan data sekunder. Sumber data primer yakni data yang diperoleh langsung dari perilaku warga masyarakat, 10 yang dalam penelitian ini diperoleh dari Hakim dan Panitera Pengadilan Agama Pemekasan, Advokat dan Notaris. Sumber primer lain yang tidak kalah pentingnya adalah data dari beberapa putusan perkara waris di Pengadilan Agama Pamekasan, yang diberbentuk Penetapan (non sengketa) Data tersebut diambil secara sampel purposif (dilakukan secara sengaja) sesuai dengan kebutuhan. ${ }^{11}$

Sedangkan data sekunder merupakan data kelengkapan dari data primer yaitu dengan membaca, memahami dan sekaligus membandingkan peraturan perUndang-Undangan antara lain Undang-Undang Nomor 7 Tahun 1989 tentang Peradilan Agama jo Undang-Undang Nomor 50 Tahun 2008, Undang-Undang Nomor 3 Tahun 2004 tentang Kekuasaaan KeHakiman jo Undang-Undang Nomor 48 Tahun 2008, Undang Undang Nomor 4 Tahun 2004 tentang Perubahan Atas UndangUndang Mahkamah Agung Nomor 14 Tahun 1985.

Instrumen pengumpulan data dalam penelitian ini menggunakan observasi dan wawancara. Jenis wawancara yang dipergunakan dalam penelitian ini adalah wawancara mendalam (depth interview). ${ }^{12}$ Yang dimaksud dengan

9 Sudarwan Danim, Menjadi Peneliti Kualitatif (Bandung: Pustaka Setia, 2002), hlm. 54 .

10 Soerjono Soekamto, Pengantar Penelitian Hukum (Jakarta: Universitas Indonesia Press, 1982), hlm. 12.

11 Suharsimi Arikunto, Prosedur Penelitian Suatu Pendekatan Praktik (Jakarta: Rineka Cipta, 1996), hlm. 127-128.

12 Soerjono Soekamto, Pengantar Penelitian Hukum, hlm. 231. 
wawancara mendalam adalah teknik pengumpulan data dengan cara bertanya secara bebas kepada interviewer (orang yang sedang diwawancarai), namun didasarkan pada panduan atau pedoman wawancara yang sebelumnya telah dibuat. Tujuan wawancara dengan pola demikian untuk memperoleh data yang lebih mendalam dan terarah sesuai dengan fokus penelitian. Metode dokumentasi yaitu mencari data mengenai hal-hal atau variabel yang berupa catatan, transkrip, agenda, berkas-berkas dan setiap bahan tertulis. Dalam hal ini Peneliti melakukan metode dokumentasi dengan cara mencari dan mengumpulkan serta menelaah dari sumber-sumber yang yang berkaitan dengan putusan-putusan dalam perkara waris yang diputus berdasarkan hukum waris Islam.

Analisis data adalah proses pelacakan dan pengaturan data secara sistematis transkrip wawancara, catatan lapangan dan bahan-bahan lain yang dikumpulkan untuk meningkatkan pemahaman terhadap bahan-bahan tersebut agar dapat dipresentasikan semuanya kepada orang lain.13 Sedangkan tahapan analisisnya adalah checking, organizing, dan coding. Checking digunakan untuk mengetahui kelengkapan data yang diperlukan dalam pengajian data. Sedangkan organizing digunakan untuk mengetahui kesesuaian data yang diperoleh dengan fokus penelitian, dan coding adalah proses pemilahan data.

\section{Temuan Penelitian} berikut:

Adapun temuan dalam penelitian ini adalah sebagai

1. Apakah Pengadilan Agama Pamekasan selalu menerapkan hukum waris Islam dalam memeriksa dan memutuskan perkara waris.

${ }^{13}$ Arifin, Penelitian Kualitatif, hlm. 84 
a. Jenis perkara dalam perkara waris yang pada umumnya diajukan di Pengadilan Agama adalah Permohonan Penetapan Waris yakni perkara waris yang non sengketa.

b. Pengadilan Agama Pamekasan dalam memeriksa perkara waris selalu mendasarkan pada asas personalitas ke-Islaman, artinya setiap perkara dalam perkara waris akan selalu mendasarkan pada al-Qur'an, Hadist, Ijtihad maupun Kompilasi Hukum Islam (KHI).

c. Dalam memutuskan jenis perkara gugatan waris maka Pengadilan Agama Pamekasan akan selalu mendasarkan pada hukum waris Islam baik dalam penentuan siapa saja ahli waris maupun bagiannya.

d. Dalam perkara permohonan waris apabila pihak-pihak menginginkan pengaturan lain dalam menentukan siapa ahli waris dan bagiannya (sebagaimana diatur dalam hukum waris Islam) maka Majelis Hakim menentukan terlebih dahulu ahli waris dan bagian masing masing berdasarkan hukum waris Islam dan kemudian ahli waris dapat membuat kesepakatan lain, yang dapat dilakukan di dalam maupun di luar persidangan.

e. Apabila pihak-pihak membuat kesepakatan lain baik mengenai ahli waris ataupun bagiannya yang berbeda dengan hukum waris Islam maka kesepakatan tersebut dilakukan di persidangan sehingga tercantum dalam putusan Hakim sehingga mempunyai kekuatan hukum yang mengikat seperti halnya isi putusan.

2. Kendala yang dihadapi Hakim Pengadilan Agama Pamekasan dalam memutus perkara waris dengan mendasarkan pada hukum waris Islam.

a. Hakim di Pengadilan Agama Pamekasan tidak mengalami kendala dalam memeriksa dan memutus dalam perkara waris dengan mendasarkan kepada hukum waris Ialam karena penerapan hukum waris Islam tersebut merupakan kewenangan Pengadilan Agama ketika pihak-pihak beragama Islam (asas personalitas ke-Islam-an). 
b. Apabila terdapat ahli waris yang mengajukan keberatan perkara warisnya diselesaikan di Pengadilan Agama dengan menerapkan hukum waris Islam maka ahli waris tersebut dapat mengajukan eksepsi ataupun mengajukan banding apabila perkara tersebut sudah diputus oleh Pengadilan Agama Pamekasan.

c. Kendala terkadang dialami oleh ahli waris yaitu terdapat ahli waris yang tidak dapat membuktikan bahwa ia merupakan ahli waris ataupun kesulitan dalam menentukan status benda (apakah termasuk benda waris ataupun tidak).

d. Apabila terdapat perbedaan dalam penentuan waris ataupun bagian waris berdasarkan hukum waris Islam maka yang akan dipakai adalah Kompilasi Hukum Islam (KHI).

\section{Pembahasan}

Pengadilan Agama sebagai salah satu dari empat lingkungan peradilan di Indonesia telah diakui eksistensinya dalam Undang-Undang Nomor 14 Tahun 1970 tentang PokokPokok Kekuasaan Kehakiman dan yang terakhir telah diganti dengan Undang-Undang Nomor 48 Tahun 2009 tentang Kekuasaan Kehakiman, merupakan lembaga peradilan khusus yang ditujukan kepada umat Islam dengan lingkup kewenangan khusus pula, baik mengenai perkaranya ataupun para pencari keadilannya.

Sebelum adanya Undang-Undang Nomor 3 Tahun 2006 Peradilan Agama seringkali disebut dengan peradilan keluarga dari orang-orang yang beragama Islam. Oleh karena itu awalnya Prof. Bustanul Arifin menyatakan bahwa Peradilan Agama disebut juga peradilan keluarga bagi orang orang yang beragama Islam, seperti yang terdapat pada negara lain (family 
court). ${ }^{14}$ Peradilan Agama sebagai peradilan keluarga dalam menjalankan fungsinya tidak seperti Peradilan Umum. Artinya hanya melaksanakan kekuasaan kehakiman secara tradisional dan kaku dalam menyelesaikan sengketa keluarga. Sebaliknya Peradilan Agama harus menempuh cara-cara yang tidak menimbulkan kerusakan rohani dan sosial bagi keluarga yang menjadi pencari keadilan. Di samping itu Peradilan Agama harus pula diarahkan sebagai lembaga preventif bagi kemungkinan-kemungkinan timbulnya keretakan keluarga yang akan menjurus kepada sengketa keluarga dan pada saat pemeriksaan perkara di persidangan harus menjaga suasana yang manusiawi dan kekeluargaan.

Namun istilah peradilan keluarga tersebut dengan adanya Undang-Undang Nomor 3 Tahun 2006 kewenangan Peradilan Agama sudah tidak mutlak lagi karena Peradilan Agama memperoleh tambahan kewenangan yaitu dalam bidang ekonomi syari'ah.

Secara umum Undang-Undang Nomor 7 Tahun 1989 tentang Peradilan Agama telah membawa perubahan yang sangat mendasar terhadap eksistensi Pengadilan Agama yaitu dengan sejajarnya Peradilan Agama dengan peradilan lainnya. Jika sebelum berlakunya Undang-Undang tersebut dalam perkara waris keputusan Pengadilan Agama tidak mempunyai kekuatan hukum yang mengikat tanpa adanya penguatan dari Pengadilan Negeri maka setelah berlakunya Undang-Undang Peradilan Agama, putusan perkara warisnya telah mempunyai kekuatan eksekutorial sebagaimana esensi dari putusan pengadilan.

Masalah waris sering menjadi masalah di tengah
masyarakat karena tidak banyak masyarakat yang

14 BusthanulArifin, PelembagaanHukum Islam di Indonesia, Akar Sejarah Hambatan danProspeknya (Jakarta: GemaInsani Press, 1996), hlm. 94. 
memahaminya baik seluk beluknya maupun sisi syara' atau hukum masalahnya. ${ }^{15}$

Menurut Pasal 49 ayat (3) Undang-Undang Nomor 7 tahun 1989 kewenangan Pengadilan Agama di bidang kewarisan mengatur tentang penentuan siapa-siapa yang menjadi ahli waris, penentuan harta peninggalan, bagian masing masing ahli waris dan melaksanakan pembagian harta peninggalan. Dalam Pasal 2 jo Pasal 49 ayat (1) Penjelasan Umum angka 2 alinea ketiga telah ditentukan bahwa salah atau asas sentral dalam Undang-Undang ini adalah asas personalitas ke-Islam-an, artinya bahwa dalam bidang kewarisan meliputi seluruh golongan rakyat yang beragama Islam.

Penerapan hukum waris Islam di Peradilan Agama dalam perkara antara orang yang beragama Islam dilaksanakan dalam rangka mewujudkan keseragaman kekuasaan Pengadilan Agama di seluruh Indonesia, yang selama ini berbeda satu sama lain karena dasar hukumnya berbeda. ${ }^{16}$ Dalam Undang-Undang Nomor 7 Tahun 1989 Pengadilan Agama juga diberi tugas dan wewenang untuk menyelesaikan permohonan pertolongan dan pembagian harta peninggalan di luar sengketa antara orang-orang yang beragama Islam yang dilakukan berdasarkan hukum Islam. ${ }^{17}$

Indikator untuk menentukan kewenangan Pengadilan Agama terhadap sengketa atau permasalahan yang terjadi dalam kehidupan masyarakat, yaitu: Pertama, Agama yang dianut oleh kedua belah pihak saat terjadinya hukum adalah agama Islam; Kedua, Hubungan ikatan hukum yang dilakukan berdasarkan hukum Islam.

${ }_{15}$ Muchsin, Hukum Islam dalam Perspektif dan Prospektif (Surabaya: Usana Offset, 2003), hlm. 66.

16 Abdul Manan, Penerapan Hukum Acara Perdata di Lingkungan Peradilan Agama, hlm. 8.

17 Ibid. 
Hukum waris dalam pembidangan hukum termasuk dalam ruang lingkup hukum perdata, yaitu hukum yang mengatur hubungan orang dengan orang. Sebagai konsekuensinya dalam hukum waris dikenal adanya hak memilih hukum (hak opsi). Hak opsi adalah hak untuk memilih sistem hukum yang dikehendaki para pihak yang berperkara sebagai acuan dalam penyelesaian suatu perkara yakni dalam perkara perdata tertentu. Salah satu dari hukum perdata adalah bersifat mengatur (regelen) dan bukan memaksa (dwingend) sehingga persetujuan para pihak yang berperkara dapat dibenarkan dalam penyelesaian sengketa.

Syarat untuk dapat diterapkannya pemilihan hukum dalam sengketa waris: Pertama, Perkara yang disengketakan belum diajukan ke pengadilan; Kedua, Adanya kesepakatan antara pihak yang berperkara. Pilihan hukum dalam bidang waris merupakan perwujudan dari asas kebebasan berkontrak (freedom of contract) yang tertuang dalam Pasal 1338 Kitab Undang-Undang Hukum Perdata yang menyatakan bahwa perjanjian yang dibuat secara sah berlaku seperti UndangUndang bagi pihak-pihak yang mengadakannya.

Pada tahun 2006 terjadi amandemen terhadap UndangUndang Peradilan Agama melalui Undang-Undang Nomor 3 Tahun 2006 tentang Perubahan Atas Undang-Undang Nomor 7 Tahun 1989 tentang Peradilan Agama. Salah satu poin penting dari adanya amandemen terhadap Undang-Undang Peradilan Agama adalah dihapuskannya permasalahan pilihan hukum. Undang-Undang Peradilan Agama yang sebelumnya menyatakan bahwa "para pihak sebelum berperkara dapat mempertimbangkan untuk memilih hukum apa yang akan dipergunakan dalam pembagian warisan".

Dalam tataran praktik pilihan hukum dalam perkara waris dapat menimbulkan permasalahan yakni apabila tidak terdapat kesepakatan diantara ahli waris dalam memilih hukum waris ataupun pengadilan yang akan menyelesaikan sengketanya. Terdapat kemungkinan akhirnya para pihak 
menunjuk Pengadilan Negeri dan Pengadilan Agama secara bersamaan. Apabila hal ini terjadi maka harus menunggu fatwa atau upaya kasasi ke Mahkamah Agung, yang nantinya akan memutuskan pengadilan mana yang berwenang untuk memeriksa, mengadili dan memutus sengketa tersebut. Upaya hukum ke Mahkamah Agung tersebut membutuhkan waktu yang tidak singkat. Hal ini tentu saja tidak sesuai dengan asas peradilan cepat, sederhana, dan biaya murah yang berlaku dalam hukum acara peradilan di Indonesia.

Di dalam Undang-Undang yang baru tersebut juga memangkas choice of law dalam hukum kewarisan. Dalam Penjelasan Umum telah dinyatakan "bahwa para pihak sebelum berperkara dapat mempertimbangkan untuk memilih hukum apa yang dipergunakan dalam pembagian warisan, dinyatakan dihapus". Menurut harfiah dari pernyataan dalam Penjelasan Umum tersebut adalah pilihan hukum sudah tidak dimungkinkan lagi. Artinya apabila pihak-pihak yang bersengketa waris beragama Islam maka sengketa waris tersebut akan menjadi kewenangan Pengadilan Agama.

Dihapuskannya pilihan hukum dalam perkara waris bagi yang beragama Islam ternyata di kalangan masyarakat masih mengandung pertanyaan karena di dalam Undang-Undang tersebut tidak terdapat penjelasan apabila terdapat permasalahan diantara ahli waris terdapat perbedaan agama dan apakah suatu perkara waris yang diselesaikan di Pengadilan Agama harus menganut atau tunduk pada hukum Islam.

Dalam praktik hukum waris di Indonesia hingga saat ini masih bersifat fleksibel karena tidak berdasar pada hukum Islam secara ansich namun mempunyai sandaran yuridis yang relatif akomodatif yakni dengan adanya hukum kewarisan yang diatur dalam Kompilasi Hukum Islam (KHI). ${ }^{18} \mathrm{Hal}$ ini dapat dilihat dari Putusan Mahkamah Agung tentang adanya wasiat

${ }^{18}$ Ibid. hlm. 67. 
wajibah terhadap harta warisan pewaris Islam anak muslim dan non muslim. Dalam putusan tersebut Mahkamah Agung memberikan bagian waris kepada seorang anak non muslim (orang tuanya beragama Islam) dan membatalkan putusan Pengadilan Agama pada tingkat pertama yang tidak memberikan bagian waris kepada anak non muslim tersebut. Putusan tersebut menimbulkan kontroversi di dalam masyarakat sebab jumhur ulama' sepakat bahwa non muslim tidak dapat mewarisi orang Islam. Meskipun wasiat wajibah dapat dipaksakan dan dijadikan landasan putusan Mahkamah Agung namun tetap sesuai dengan syari'at Islam yaitu penerima waris harus seagama atau sesama muslim. Hal ini menunjukan adanya aktualita pemikiran terhadap perUndangUndangan yang berlaku. ${ }^{19}$

Konsekuensi dari dihapuskannya pilihan hukum waris dalam perkara waris bagi orang yang beragama Islam adalah dalam perkara waris baik dalam bentuk gugatan maupun permohonan selalu akan menjadi kewenangan dari Pengadilan Agama dan Pengadilan Agama akan menerapkan hukum waris Islam. Sebaliknya Pengadilan Negeri yang merupakan Peradilan Umum tidak dapat menerima dan memutuskannya selama para pihak beragama Islam. Sebelum adanya UndangUndang Nomor 3 Tahun 2006 Pengadilan Negeri dapat menerima dan memutus perkara waris dengan mendasarkan pada hukum waris adat maupun hukum waris Barat (BurgerlijkWetboek) bagi keturunan Tionghoa. Namun setelah adanya Undang-Undang tersebut Pengadilan Negeri secara hukum harus menolak perkara waris yang diajukan oleh orang Islam karena sudah merupakan kewenangan absolut dari Pengadilan Agama.

Urgensi penelitian ini dilakukan dengan alasan dalam praktik pada masyarakat Pamekasan masih banyak yang menerapkan hukum waris adat. Di masyarakat hukum waris 
adat lebih mengemuka dibandingkan dengan hukum waris Islam. Bukti kuatnya penerapan hukum waris adat pada masyarakat Pamekasan antara lain orang tua telah membagi hartanya ketika masih hidup. Di dalam hukum adat pemberian semasa hidup tersebut merupakan salah satu proses pewarisan sehingga ketika orang tua meninggal dunia maka secara otomatis harta waris telah habis terbagi diantara ahli waris. Praktik lainnya pada umumnya masyarakat ketika akan membagi waris akan mengajukan Surat Keterangan Waris ke Kantor Kecamatan dengan diketahui oleh Kepala Desa atau Lurah setempat. Padahal dasar pembagian waris yang digunakan dalam Surat Keterangan Waris tersebut mendasarkan pada hukum waris adat. Tentu saja penentuan ahli waris ataupun bagian waris berdasarkan hukum waris Islam dan hukum waris adat adalah berbeda.

Sebelum berlakunya Undang-Undang Nomor 3 Tahun 2006 pemilihan hukum dalam penentuan hukum waris masih diperkenankan sehingga masyarakat masih dapat memilih hukum waris selain hukum waris Islam, misalnya hukum waris adat ataupun hukum waris Barat yang merupakan kewenangan Pengadilan Negeri. Hal ini berbeda setelah berlakunya UndangUndang tersebut maka Pengadilan Agama merupakan satu satunya pengadilan yang akan memutus perkara baik permohonan maupun gugatan dalam perkara waris. Dengan demikian bagi masyarakat yang menganut agama Islam mau tidak mau harus mengajukan ke Pengadilan Agama.

Berdasarkan data yang peneliti peroleh dari website Pengadilan Agama Pamekasan sangatlah nampak bahwa masyarakat Pamekasan masih sangat minim jumlahnya yang mengajukannya ke Pengadilan Agama Pamekasan. Rata-rata setiap tahunnya hanya 2 atau 3 perkara saja. Dari jumlah yang minim tersebut mayoritas adalah perkara permohonan waris. Perkara permohonan waris adalah upaya dari ahli waris yang telah sepakat untuk membagi benda warisnya ke Pengadilan Agama dan diantara ahli tidak terdapat perselisihan. Pada 
umumnya tujuan masyarakat mengajukan ke Pengadilan Agama agar pembagian waris memperoleh legalitas.

Menjadi pertanyaan besar peneliti apabila perkara yang masuk ke Pengadilan Agama hanya 2 atau 3 setahun, masyarakat lainnya membagi warisnya dengan menggunakan hukum apa? Dari uraian di atas sepintas dapat dikatakan bahwa terdapat kesenjangan hukum di masyarakat. Hal ini dapat menimbulkan adanya perbedaan antara hukum yang hidup di masyarakat (living law) dengan hukum yang ada di perUndang-Undangan (law in book). Kesenjangan tersebut dapat menimbulkan masalah di belakang hari apabila benda waris sudah dibagi dengan mendasarkan pada hukum waris adat, namun kemudian dipersoalkan lagi dan menjadi perkara di Pengadilan Agama. Tentu saja Pengadilan Agama akan mendasarkan pada hukum waris Islam.

Semangat Undang-Undang Peradilan Agama tersebut berbeda apabila dibandingkan dengan kenyataan hukum yang berlaku di masyarakat Pamekasan. Masyarakat Pamekasan hingga saat ini masih menganut hukum waris adat. Dianutnya hukum waris adat tercermin dalam beberapa hal misalnya dalam membagi waris portie antara anak laki laki dan anak perempuan adalah relatif sama (dalam hukum Islam 2:1) atau kedudukan janda atau duda yang hanya sebatas menguasai benda waris selama hidup dan belum kawin lagi (dalam hukum waris Islam janda dan duda selalu menjadi ahli waris dari pasangannya yang meninggal dunia).

Yang paling mencolok adalah masyarakat Pamekasan pada umumnya tetap mengurus Surat Keterangan Waris di Kepala Desa/Kecamatan setempat. Ketika mengurus Surat Keterangan Waris maka akan disertai dengan Surat Pernyataan Ahli Waris. Surat Pernyataan Ahli Waris tersebut dibuat secara sepihak oleh para ahli waris dan menyatakan bahwa tidak ada ahli waris lain selain yang tertera di dalam Surat Keterangan Waris tersebut. Surat Keterangan Waris tersebut mendasarkan pada hukum waris adat. Surat Keterangan Waris pada 
umumnya digunakan oleh masyarakat untuk balik nama sertifikat yang tertulis atas nama pewaris. Surat Keterangan Waris tersebut akan menjadi dasar bagi Kantor Pertanahan Nasional (BPN) dalam pengurusan balik nama sertifikat.

Masalah yang dapat timbul dari Surat Keterangan Waris yang mendasarkan pada hukum waris adat tersebut apabila orang-orang yang menjadi ahli waris ternyata tidak sama dengan apabila benda waris tersebut diselesaikan dengan hukum waris Islam. Dengan demikian tidak tertutup kemungkinan setelah benda waris, misalnya tanah atau rumah tersebut sudah dibalik nama (sudah atas nama ahli waris) ternyata terdapat pihak lain yang tidak termasuk dalam ahli waris menurut hukum waris Islam menggugat pembagian waris tersebut ke Pengadilan Agama.

Akibatnya sertifikat yang dikeluarkan oleh Kantor Pertanahan Nasional akan dapat dibatalkan oleh putusan Pengadilan Agama yang mendasarkan pada hukum waris Islam. Apabila hal ini terjadi akan merupakan suatu keadaan yang tidak baik dalam koridor hukum karena sertifikat yang merupakan akta otentik dengan mudahnya dibatalkan oleh pengadilan.

Sebagaimana sudah diuraikan dalam paparan data di atas bahwa Hakim Pengadilan Agama akan selalu menerapkan hukum waris Islam di dalam perkara waris baik dalam perkara gugatan maupun dalam perkara permohonan. Pada umumnya perkara waris yang diajukan adalah permohonan. Perkara permohonan merupakan jenis perkara non sengketa. Pada perkara permohonan Majelis Hakim lebih bersikap administratif. Apabila semua persyaratan dalam perkara permohonan itu sudah lengkap maka Hakim kemudian akan memutuskan. Alasan perkara permohonan waris yang diajukan masyarakat di Pengadilan Agama Pamekasan misalnya karena tidak ada ahli waris yang utama (misalkan anak) atau mengajukan permohonan penetapan waris guna pengajuan kredit. 
Permohonan penetapan waris karena tidak ahli waris yang utama merupakan alasan yang dominan dalam praktik di Pengadilan Agama Pamekasan. Masyarakat pada umumnya ingin memperoleh kepastian hukum siapa saja ahli waris dari seseorang yang tidak memiliki keturunan. Sedangkan pengajuan permohonan penetapan waris yang diperuntukkan untuk pengajuan kredit disebabkan sertifikat yang diagunkan masih atas nama pewaris sehingga pihak perbankan pada umumnya akan mensyaratkan adanya penetapan ahli waris dari Pengadilan Agama. Ketentuan dari pihak penyedia kredit/bank tersebut merupakan langkah yang tepat dengan tujuan memastikan siapa ahli waris dengan mendasarkan pada agama yang dianut oleh pewaris ataupun oleh ahli waris. Berdasarkan fakta yang diperoleh penulis bahwa pihak perbankan tidak merekomendasikan Surat Keterangan Waris dibuat oleh kecamatan karena Surat Keterangan Waris tersebut didasarkan pada hukum waris adat.

Menurut pendapat penulis idealnya terdapat suatu aturan tertulis yang melarang Kepala Desa/Kecamatan membuat Surat Keterangan Waris yang diajukan oleh masyarakat yang beragama Islam dan mengharuskan mengajukannya di Pengadilan Agama.

Sebagaimana paparan di atas di Pengadilan Agama terdapat dua jenis perkara yaitu perkara gugatan waris (berarti ada 2 pihak atau lebih, ada sengketa) dan permohonan penetapan waris (yang tidak mengandung sengketa). Apabila diantara ahli waris tidak terdapat sengketa maka mengajukan permohonan. Pengadilan Agama dalam memeriksa dan memutus perkara waris akan tetap mendasarkan pada hukum waris Islam baik dalam penentuan siapa yang akan menjadi ahli waris maupun bagian-bagian dari ahli waris. Namun demikian setelah Pengadilan Agama menentukan ahli waris dan bagiannya maka ahli waris dapat mengatur pembagian waris secara musyawarah. Dari musyawarah tersebut apabila terdapat kesepakatan maka dapat menyimpangi sebagaimana 
yang diatur dalam hukum waris Islam tergantung keinginan dari ahli waris. Dengan demikian maka Pengadilan Agama akan selalu memiliki kewenangan dalam menyelesaikan perkara waris antarorang yang beragama Islam. Misalnya dalam pembagian waris akan membagi 1:1 maka masih diperkenankan yakni dengan jalan permohonan penetapan waris. Larangan Kepala Desa/Kecamatan untuk membuat Surat Keterangan Waris sangatlah berarti bagi masyarakat yakni memberikan kepastian hukum dalam menentukan siapa-siapa yang menjadi ahli waris maupun bagian warisannya.

\section{Penutup}

Rekomendasi penelitian ini ditujukan pada: Pertama, Bagi Badan Legislatif, bahwa keinginan perUndang-Undangan dalam penerapan hukum waris Islam bagi orang Islam ketika menjadi perkara di Pengadilan Agama masih dapat menimbulkan permasalahan karena living law perkara waris di dalam masyarakat adalah hukum waris adat. Kesenjangan tersebut dapatlah diminimalisir dengan dilarangnya kecamatan setempat untuk membuat Surat Keterangan Waris yang nyatanyata mendasarkan pada hukum waris adat. Dihapuskannya kewenangan kecamatan dalam membuat Surat Keterangan Waris akan memberikan kepastian hukum kepada masyarakat. Kedua, Bagi Pemerintah, perlunya sosialisasi kepada masyarakat tentang hukum waris Islam mengingat selama ini masih banyak masyarakat yang belum memahami tentang hukum waris Islam terlebih kewenangan Pengadilan Agama dalam menangani dan memutus perkara waris yang beragama Islam. Sosialisasi lainnya adalah anjuran kepada masyarakat agar ketika membutuhkan Surat Keterangan Waris tidak lagi mengurusnya di kantor kecamatan setempat melainkan mengurus ke Pengadilan Agama. Ketiga, Bagi Pengadilan Agama, dalam memutuskan perkara waris dengan mendasarkan pada hukum waris Islam sama sekali mengenyampingkan hukum waris lainnya di dalam masyarakat sehingga putusan yang dihasilkan 
akan memenuhi rasa keadilan di dalam masyarakat. Dan bersama pemerintah selalu memberikan sosialisasi kepada masyarakat tentang kewenangan Pengadilan Agama dalam menangani dan memutus perkara waris bagi orang yang beragama Islam.

\section{Daftar Pustaka}

Afdol, Landasan Hukum Positif Pemberlakuan Hukum Islam dan Permasalahan Implementasi Hukum Kewarisan Islam. Surabaya: Airlangga Press, 2003.

Ali, Zainuddin. Hukum Islam: Pengantar Ilmu Hukum Islam di Indonesia. Jakarta: Sinar Grafika, 2006.

Anshori, Abdul Ghofur. Peradilan Agama di Indonesia (Pasca Undang-Undang Nomor 3 Tahun 2006 Sejarah, Kedudukan dan Kewenangan. Yogyakarta: UII Press, 2007.

Arifin, Busthanul. Pelembagaan Hukum Islam di Indonesia, Akar Sejarah Hambatan dan Prospeknya. Jakarta: GemaInsani Press, 1996.

Arikunto, Suharsimi. Prosedur Penelitian Suatu Pendekatan Praktik. Jakarta: Rineka Cipta, 1996.

Danim, Sudarwan. Menjadi Peneliti Kualitatif. Bandung: Pustaka Setia, 2002.

Djalil, H.A. Basiq. Peradilan Agama di Indonesia. Jakarta: Prenada Media Group, 2006.

Harahap, M. Yahya. Kedudukan Kewenangan dan Acara Peradilan Agama UU No 7 Tahun 1989. Jakarta: Pustaka Kartini, 1993.

Lubis, Sulaikin. dkk, Hukum Acara Perdata Peradilan Agama di Indonesia. Jakarta: Prenada Media, 2005.

Mannan, Abdul. Penerapan Hukum Acara Perdata di Lingkungan Peradilan Agama. Jakarta: Prenada Media Group, 2006.

Mardani. Hukum Acara Perdata Peradilan Agama. Jakarta: Sinar Grafika, 2007.

Moelong, Lexy J. Metode Penelitian Kualitatif. Bandung: Remaja Rosdakarya, 1990. 
Muchsin. Hukum Islam dalam Perspektif dan Prospektif . Surabaya: Usana Offset, 2003.

Muhibbin dan Abdul Wahid. Hukum Kewarisan Islam Sebagai Pembaharuan Hukum Positif di Indonesia. Jakarta: Sinar Grafika, 2009.

Rasyid, Roihan A. Hukum Acara Peradilan Agama. Jakarta: Rajawali Press, 1991.

Rofiq, Ahmad. Pembaharuan Hukum Islam di Indonesia. Yogyakarta: Gama Media, 2001.

Siddik, Abdullah. Hukum Waris Islam dan Perkembangannya di Seluruh Dunia Islam. Jakarta: Widjaja, 1984.

Soekamto, Soerjono. Pengantar Penelitian Hukum. Jakarta: Universitas Indonesia Press, 1982.

Suparman, Eman. Intisari Hukum Waris Indonesia. Bandung: Mandar Maju, 1991.

Suryabrata, Sumadi. Metode Penelitian. Jakarta: Rajawali Pers, 1991.

Syarifuddin, Amir. Hukum Kewarisan Islam. Jakarta: Prenada Media, 2004.

Warsito, Hermawan. Pengantar Metodologi Penelitian. Jakarta: Gramedia Pustaka Utama, 1993.

Wigjosoebroto, Soetandyo. Hukum: Paradigma Metode dan Dinamika Masalahnya. Jakarta: Elsam dan Huma, 2002. 